\title{
Household Behavior towards Debt in a Challenging Financial Environment in Malaysia
}

\author{
Siti Aminah Mainala ${ }^{a}$ Catherine S F Hob ${ }^{b}$ Jamaliah Mohd Yusof ${ }^{b}$ \\ aFaculty of Business and Management, Universiti Teknologi MARA, Puncak Alam 42300, Malaysia \\ bFaculty of Business and Management, Universiti Teknologi MARA, Shah Alam 40450, Malaysia \\ stiaminah844@salam.uitm.edu.my
}

\begin{abstract}
The study of household behaviour towards debt is important in this challenging financial environment. Escalating household debt can cause social and economic problems. For the past few years Malaysia has emerged as the highest household debt country in the ASEAN region. Therefore this study aims to examine the predictors of intention to incur household debt among Malaysian households. Analysis on 100 usable questionnaires in the pilot study revealed financial literacy and subjective norm as significant predictors of attitude and the mediating relationship between attitude and intention to incur on household debt was found to be negatively significant.
\end{abstract}

Keywords: Household behaviour; household debt; financial environment; financial literacy

2398-4295 @ 2017 The Authors. Published for AMER ABRA by e-International Publishing House, Ltd., UK. This is an open access article under the CC BY-NC-ND license (http://creativecommons.org/licenses/by-nc-nd/4.0/). Peer-review under responsibility of AMER (Association of Malaysian Environment-Behaviour Researchers), ABRA (Association of Behavioural Researchers on Asians) and CE-Bs (Centre for Environment-Behaviour Studies), Faculty of Architecture, Planning \& Surveying, UniversitiTeknologi MARA, Malaysia.

http://dx.doi.org/10.21834/ajbes.v2i7.39 


\section{Introduction}

It was excessive household debt that triggered the global financial crisis which started in the United States (U.S.) in 2007 that led to severe worldwide financial instability. In the current challenging financial environment, household debt is still escalating hence causing high levels of financial anxiety. The challenge of paying down debt, be it housing, automotive, education or credit cards can be overwhelming especially in a weak financial environment. There are also many financial and social problems arising due to household debt burden apart from the above mentioned troubling ratios. Some of these financial problems include cash flow problems, loan defaults, foreclosures and even bankruptcies. Meanwhile, social implications such as psychological distress, depression, anxiety and anger, marital instability, divorce and even suicidal ideation and contemplation can be the results of too much household debt. The study of household behaviour towards debt, therefore, is vital at the current state of household debt situation globally and that includes Malaysia too. In Malaysia, bankruptcy cases among young adults are on the rise. This issue should be of great concerned since young and mature adults are supposed to be the main resources that can contribute to the economy of a country.

The main objective of this study is to determine the predictors of intention to incur household debt among Malaysian households. Thus, this study is aimed to examine the role of attitude as a mediating variable in relations between financial literacy, subjective norm, perceived behavioural control and intention to incur household debt.

\section{Literature Review}

\subsection{The proposed theoretical model}

Figure 1 depicts the proposed hypothetical model for the current study. Variables such as attitude, subjective norm and perceived behavioural control (PBC) are recognized as factors of Theory of Planned Behaviour (TPB) developed by Ajzen (1991) that have been widely studied in the context within the psychology field and also marketing field. The TPB has also been applied in studies relating to indebtedness or debt burden. These studies range from areas concerning financial well-being, financial self-confidence, budget control, intention to borrow, risky credit behaviour and convenience use of credit card debt (Chudry, Foxall, \& Pallister, 2011; Rutherford \& Devaney, 2009). Meanwhile, for financial literacy, past empirical studies have shown that participation in the stock market, household wealth and financial decision making are associated with lower levels of financial literacy (Guiso \& Jappeli, 2008; Rooij, Lusardi, \& Alessie, 2007). Therefore, the model for the current study examines the relationship between TPB variables and an additional variable, financial literacy and intention to incur household debt. 


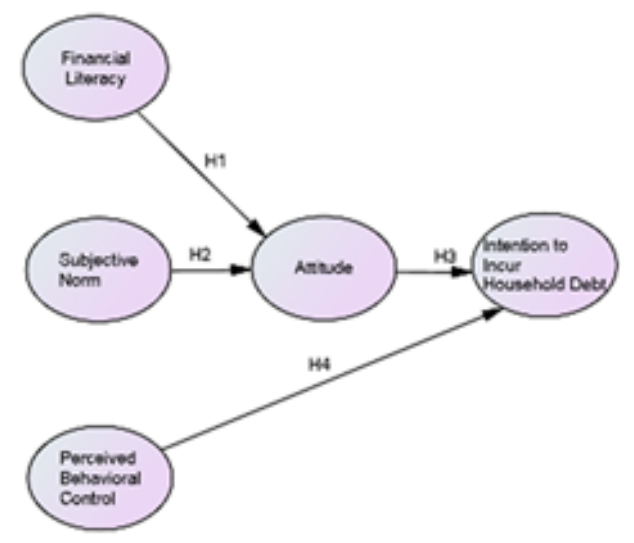

Figure 1: Proposed Hypothetical Model

\subsection{Financial literacy}

Financial literacy measures a specific construct that has been widely studied within the broad field of social science, including psychology, economics and sociology (Chudry et al., 2011; Jorgensen \& Savla, 2010). In considering these factors, financial literacy meets all of Ajzen (2008) criteria for being added as a predictor. According to Kennedy (2013), as researchers have suggested that those with a lack of financial literacy possess greater sums of credit card debt, it is conceivable that financial literacy is a causal factor in determining the behavioural intention to use credit cards and acquire credit card debt.

\subsection{Subjective Norm}

With regards to behaviour towards debt, Carpenter and Reimers (2005), described subjective norm could be the influence of family members, friends and others that were close to the individual and could, therefore, change when the opinions and ideas of these individuals close to them change. This was supported by Chudry et al. (2011) who posited that friends and parents were also recognized as the source of subjective norms.

\subsection{Perceived behavioural control (PBC)}

PBC has also been a predictor in the context of debt. Madden, Ellen, and Ajzen (1992) stated that control is attained through relevant resources and opportunities for performing a given behaviour. This was supported by Rutherford and Devaney (2009), who stated that the more resources and opportunities individuals thought they possessed, the higher their perceived behavioural control. 


\subsection{Attitude}

Numerous previous researchers have examined various human behaviours and confirmed the relationships between attitude and behavioural intention by using the TPB. Some researchers had shown that attitude towards money usage and credits were significant determinants of debt behaviour (Stone \& Maury, 2006; Tokunaga, 1993). However, this scenario of a positive relationship was not always the case. Tokunaga (1993), who did a study on households and debt, found that households, who incurred on debt or possessed credit cards, had low positive attitude towards debt as compared to households who had no debt. To support these differing results was Zhu and Meeks (1994) who revealed that there was no relationship between credit attitude and credit debt among low income family. Therefore, such inconsistent results to some extent confirmed (Ajzen \& Fishbein, 1977) allegation that the relationship between attitude and behaviour is complicated.

\subsection{Intention to incur household debt}

In finance, intention has been investigated in many different areas. Among the studies were on an intention to use credit card by Xiao, Tang, Serido, and Shim (2011) and intention to manage cash and debt wisely among young adults (Shim, Xiao, Barber, \& Lyons, 2009). These past studies on intention form the basis of the conceptual framework of the study of household behaviour towards debt in a challenging financial environment.

\subsection{Hypothesis statement}

By preceding findings, the hypotheses guiding this study propose the following: Hypothesis 1: Financial literacy has a significant positive effect on attitude Hypothesis 2: Subjective norm has a significant positive effect on attitude Hypothesis 3: Attitude has a significant effect on intention to incur household debt Hypothesis 4: Perceived behavioural control has a significant positive effect on intention to incur household debt.

\section{Methodology}

\subsection{Instrument development}

To measure attitude, 14 items developed by (Lea, Webley, \& Walker, 1995; Pattarin \& Cosma, 2012) were adapted and refined to suit the current study context. To measure subjective norm, the researchers adopted the measurement by Kennedy and Wated (2011). To measure perceived behavioural control, the researchers adopted the measurement developed by Kennedy and Wated (2011) and Rutherford and Devaney (2009). The researchers used 8 questions to measure financial literacy developed by AAUW (2010). To measure intention to incur household debt, 12 items developed by Kennedy and Wated 
(2011) were adopted and refined to suit the current study context. Each of the items was presented on a seven-point scale ranging from 'strongly disagree' (1) to 'strongly agree' (7).

\subsection{Sample and procedure}

In this pilot study, the questionnaires were distributed to households in Klang Valley, Malaysia. The survey sample of this study was composed of heads of households. 150 questionnaires were distributed and 108 collected and completed and 100 contained usable data. Of the total respondents, $72 \%$ were male head of households and only $28 \%$ female head of households. Most participants were aged from 30 to $39(39 \%)$ and married with children accounted for $61 \%$ of the sample. $53 \%$ of the respondents possessed a bachelor's degree and monthly gross household income between RM3,001 and RM6,000 represented $43 \%$. Respondents with total current household debt of RM150, $001-\mathrm{RM} 300,000$ represented $34 \%$.

\subsection{Data Analysis}

Data were analysed by using SPSS 21 package. Descriptive statistics was also used to distinguish the demographic information of respondents and to identify households' behaviour pertaining to intention to incur household debt. In addition, factor analysis was also used to evaluate all the variables. Principal component analysis with varimax rotation was used to reduce the data. Minimum eigenvalues of 1.0 and with items loading above 0.50 were applied to determine the number of factors for each scale. For scale reliability, Cronbach alpha value was tested. Cronbach alpha coefficients for each factor ranged from 0.79 to 0.87 , indicating that all multi-items variables were internally consistent. The five variables in the proposed framework were tested using the regression analysis.

\section{Results and Discussions}

\subsection{Sample characteristics}

Table 1 shows the summary results of the descriptive analysis of each of the variables. Regarding attitude, the highest mean score is represented in an item where borrowed money should be repaid as soon as possible, with a mean score of 6.31 . The overall mean score of 4.67 indicates that the respondents have rated moderately positive in attitude. For subjective norm, the highest mean score of 5.50 is on the item regarding households' believed that their friends consider it important to pay off their instalment in full each month. The overall mean score of 4.83 indicates that household considers subjective norm to be reasonably important in their decision to incur household debt. For perceived behavioural control, an item which indicates that it was mostly up to the head of household as to whether or not he/she stays out of household debt, record the highest mean score of 5.15. The overall mean score of 4.39 indicates that households find that they have moderate 
perceived behavioural control to stay out of household debt. About the financial literacy variable, an item which is about knowing the difference between a credit and a debit card has the highest mean score of 6.29 . The overall results with an overall mean value of 5.02 provide evidence that households are moderately financial literate.

Overall, of all the four variables, financial literacy has reported as having the highest mean.

Table 1: Descriptive statistics summary of attitude, subjective norm, perceived behavioural control and financial literacy

\begin{tabular}{lll}
\hline Attitude & Mean Score & Std. Dev. \\
\hline $\begin{array}{l}\text { Borrowed money should be repaid as soon as } \\
\text { possible }\end{array}$ & 6.31 & 1.17 \\
Overall mean & 4.67 & \\
\hline Subjective norm & Mean Score & Std. Dev. \\
\hline $\begin{array}{l}\text { My friends consider it important to pay off their } \\
\text { instalment in full each month }\end{array}$ & 5.50 & 1.32 \\
$\begin{array}{l}\text { Overall mean } \\
\text { Perceived behavioural control }\end{array}$ & 4.83 & \\
\hline $\begin{array}{l}\text { It is mostly up to me as to whether or not I stay out } \\
\text { of household debt }\end{array}$ & 5.15 & 1.53 \\
$\begin{array}{l}\text { Overall mean } \\
\text { Financial literacy }\end{array}$ & 4.39 & \\
\hline $\begin{array}{l}\text { I know the difference between a credit and a debit } \\
\text { card } \\
\text { Overall mean }\end{array}$ & Mean Score & Std. Dev. \\
\hline & 5.29 & 1.15 \\
\hline
\end{tabular}

\subsection{Hypothesis tests}

The relationship between the independent variables - financial literacy, subjective norm, perceived behavioural control and mediating variable, attitude, and the dependent variable - intention to incur household debt was examined using a series of linear regression analysis. Financial literacy and subjective norm are significantly predictive of attitude $(R$ squared $=0.23)$. Financial literacy is significantly predictive of attitude $(\beta=0.20, p<0.05)$. Hence $\mathrm{H} 1$ was accepted. Subjective norm is also significantly predictive of attitude ( $\beta=$ $0.40, p<0.05)$. Hence $H 2$ was accepted. The mediating relationship between attitude and intention to incur on household debt $(\mathrm{H} 3)$ was found to be negatively significant $(\beta=-0.23, p$ $<0.05$ ) and thus supporting $\mathrm{H} 3$. $\mathrm{H} 4$, which links perceived behavioural control and intention to incur household debt was found not significant $(\beta=-0.10, p>0.05)$ and $\mathrm{H} 4$ is not supported. A summary of the results is depicted in Table 2. 
Table 2: Results of the Tested Hypotheses

\begin{tabular}{|c|c|c|c|c|}
\hline & Hypotheses no. and hypothesized paths & $\begin{array}{c}\text { Standardized } \\
\text { Coefficient }\end{array}$ & $\mathrm{t}$-value & $\begin{array}{c}\text { Significance } \\
\text { Level }\end{array}$ \\
\hline H1 & Financial literacy & 0.20 & 2.23 & 0.028 \\
\hline H2 & Subjective norm & 0.40 & 4.4 & 0.000 \\
\hline H3 & $\begin{array}{l}\text { Attitude } \\
\text { PBC } \rightarrow \text { intention to incur household debt } \\
\text { incur household debt }\end{array}$ & -0.23 & -2.38 & 0.019 \\
\hline H4 & $\begin{array}{l}\text { *Significant at } \\
p<0.05(t>1.96)\end{array}$ & -0.10 & -1.02 & 0.312 \\
\hline
\end{tabular}

\section{Conclusion}

This study addresses an investigation on household behaviour towards debt in a challenging financial environment by examining financial literacy, subjective norm, and perceived behavioural control, mediated by the attitude on the intention to incur household debt. Results from the descriptive analysis indicated that households possessed slightly above moderate financial literacy when it comes to managing their personal finance. Similarly subjective norm also recorded slightly moderate result and this indicates that family members and friends do play an important role in influencing households to incur debt. However, low attitude indicated that households actually do not like the idea of borrowing if they can avoid it as much as possible. Similarly for PBC, the result is low because households find that it is beyond their control when it comes to incurring debt. The hypothesis test result indicated that financial literacy and subjective norm have a significant relationship with attitude. This result supports previous findings by Kennedy (2013) that financial literacy can be a causal factor in determining the attitude and subsequently behavioural intention to use credit cards, in this case, household debt. Meanwhile, Rutherford and Devaney (2009) found a link between subjective norm and household credit card usage, affirming that households' willingness to finance expenses were commonly a result of social pressure. Meanwhile the mediating attitude has negative significant relationship with intention to incur household debt. This result supports previous findings by Tokunaga (1993), who did a study on households and debt, found that households, who incurred on debt or possessed credit cards, had a low attitude towards debt as compared to households who had no debt. To support these differing results was Zhu and Meeks (1994) who revealed that there was no relationship between attitude and credit debt among lowincome family. Therefore, such inconsistent results to some extent confirmed Ajzen and Fishbein (1977) allegation that the relationship between attitude and behavioural intention is 
complicated. However, PBC has no significant relationship with intention to incur household debt. A possible explanation for this is that the sample size for this study is low (100) since this is only a pilot test. The researchers would expect that if the sample size is higher, the result obtained would be different.

This study has contributed to the area of research with regards to household behaviour towards debt in a challenging financial environment. The findings of this study will provide a new source of reference to assist relevant authorities namely AKPK in Malaysia and financial planners in educating and instilling awareness among the public about the predictors of household behaviour towards debt in order to prevent an extreme level of household indebtedness to set in.

\section{Acknowledgement}

The authors would like to thank Universiti Teknologi MARA for the resources available to conduct this study.

\section{References}

Ajzen, I. (1991). The theory of planned behavior. Organizational Behavior and Human Decision Processes, 50(2), 179-211.

Ajzen, I. (2008). Consumer attitudes and behavior. Handbook of Consumer Psychology, 525-548.

Ajzen, I., \& Fishbein, M. (1977). Attitude-Behavior Relations: A Theoretical Analysis and Review of Empirical Research. Psychological Bulletin, 84(5), 888-918.

American Association of University Women [AAUW]. (2010). Financial Literacy. Retrieved from www.aauwca.org/index.cfm/go/pages.view/page/financial-literacy

Carpenter, T. D., \& Reimers, J. L. (2005). Unethical and Fraudulent Financial Reporting: Applying the Theory of Planned Behavior. Journal of Business Ethics, 60(2), 115-129.

Chudry, F., Foxall, G., \& Pallister, J. (2011). Exploring Attitudes and Predicting Intentions: Profiling Student Debtors Using an Extended Theory of Planned Behavior. Journal of Applied Social Psychology, 41(1), 119-149.

Guiso, L., \& Jappeli, T. (2008). Financial Literacy and Portfolio Diversification. EUI Working Papers, ECO 2008/31. Jorgensen, B. L., \& Savla, J. (2010). Financial Literacy of Young Adults: The Importance of Parental Socialization. Family Relations, 59(4), 465-478.

Kennedy, B. P. (2013). The theory of planned behavior and financial literacy: A predictive model for credit card debt? Dissertation, (August).

Kennedy, B. P., \& Wated, G. (2011). Predicting credit card debt among college students: The attitudes-behavior relation. Journal of Psychology and Behavioral Sciences, 22, 43-50. 
Lea, S. E. G., Webley, P., \& Walker, C. M. (1995). Psychological factors in consumer debt: Money management, economic socialization, and credit use. Journal of Economic Psychology, 16(4), 681-701.

Madden, T., Ellen, P., \& Ajzen, I. (1992). A comparison of the theory of planned behavior and the theory of reasoned action. Personality and Social Psychology Bulletin, 18.

Pattarin, F., \& Cosma, S. (2012). Psychological determinants of consumer credit: the role of attitudes. Review of Behavioral Finance, 4(2), 113-129.

Rooij, M. Van, Lusardi, A., \& Alessie, R. (2007). Financial Literacy and Stock Market Participation. National Bureau of Economic Research Working Paper Series, No. 13565(Working Paper 13565), 1-48.

Rutherford, L. G., \& Devaney, S. A. (2009). Utilizing the Theory of Planned Behavior to Understand Convenience Use of Credit Cards. Journal of Financial Counseling and Planning, 20(2).

Shim, S., Xiao, J. J., Barber, B. L., \& Lyons, A. C. (2009). Pathways to life success: A conceptual model of financial well-being for young adults. Journal of Applied Developmental Psychology, 30(6), 708-723.

Stone, B., \& Maury, R. V. (2006). Indicators of personal financial debt using a multi-disciplinary behavioral model. Journal of Economic Psychology, 27(4), 543-556.

Tokunaga, H. (1993). The use and abuse of consumer credit: Application of psychological theory and research. Journal of Economic Psychology, 14(2), 285-316.

Xiao, J. J., Tang, C., Serido, J., \& Shim, S. (2011). Antecedents and consequences of risky credit behavior among college students: Application and extension of the Theory of Planned Behavior. Journal of Public Policy \& Marketing, 30(2), 239-245.

Zhu, L. Y., \& Meeks, C. B. (1994). Effects of low income families' ability and willingness to use consumer credit on subsequent outstanding credit balances. Journal of Consumer Affairs, 28(2), 403-422. 